\title{
REVIEW
}

\section{Geological evolution of the northern and northwestern Eastern Ghats Belt, India from metamorphic, structural and geochronological records: An appraisal}

\author{
Proloy GANGuly* ${ }^{*}$ and Amitava ChatTERJEE** \\ ${ }^{*}$ Centre for Advanced Study, Department of Geology, Presidency University, Kolkata 70007, India \\ ** Department of Earth Sciences, Indian Institute of Technology Bombay (IITB), Mumbai 400076, India
}

\begin{abstract}
The Eastern Ghats Belt of India remains a focus of intense research by the international geoscience community to understand the Proterozoic crustal evolution. This terrane experienced anomalous thermal perturbation at least two times in Earth's history and those are linked with the assembly of two Proterozoic supercontinents. It is clearly demonstrated from existing rock records that the terrane experienced multiple events of metamorphism, magmatism, and deformation characterizing separate crustal provinces. Despite this, a clear gap in understanding the evolution of this terrane particularly on its northern and northwestern part still exists. The present review presents an update of these issues which can be taken into consideration for future research of this complex terrane.
\end{abstract}

Keywords: Eastern Ghats Belt, Proterozoic era, Accretionary orogeny, Metamorphism, Deformation, Geochronology

\section{INTRODUCTION}

The Indian continental fragment preserves some of the high-temperature metamorphic terranes including the Aravalli Fold Belt (AFB), Central Indian Tectonic Zone (CITZ), Southern Granulite Terrane (SGT), and the Eastern Ghats Belt (EGB) which flank the oldest continental nuclei namely the Dharwar, Bastar, Bundelkhand, and Singhbhum cratons. Of these, the SGT, CITZ, and the EGB have gained much attention because these were affected by regional-scale ultrahigh temperature (UHT) metamorphism during Proterozoic-Cambrian time. Although the UHT metamorphism in SGT (Santosh et al., 2009; Brandt et al., 2011 among several others) and CITZ (Bhowmik, 2019 and references therein) are relatively recent discoveries, the UHT metamorphism in EGB was reported long back (Lal et al., 1987; Dasgupta and Sengupta, 2003 and references therein). The EGB has a complex accretionary history and interpreted to represent an amalgam of several discrete crustal provinces and domains (Dobmeier and Raith, 2003; reviewed in Karmakar et al., 2009). Formation and evolution of this terrane is in-

doi:10.2465/jmps.190827b

P. Ganguly, pganguly06@gmail.com Corresponding author terpreted to be linked to the portions of the East Antarctica during the formation of the two Proterozoic supercontinents namely the Columbia and the Rodinia (Dasgupta and Sengupta, 2003; Karmakar et al., 2009; Upadhyay et al., 2009; Bose et al., 2011; Dasgupta et al., 2013; Sarkar et al., 2015; Dasgupta et al., 2017; Bose and Dasgupta, 2018). The southern part of this thousand-kilometer-long belt witnessed UHT metamorphism at $\sim 1.6 \mathrm{Ga}$ during the amalgamation of the Dharwar Craton of India with the Napier Complex of East Antarctica to be a part of the Mesoproterozoic supercontinent Columbia (Mezger and Cosca, 1999; Bose et al., 2011). However, the UHT metamorphism at the central part of this belt is relatively younger (1.0-0.9 Ga) and evolved due to accretion of the Bastar Craton of India and the cratonic blocks of East Antarctica (Ruker Province, Southern Prince Charles Mountain) at $\sim 1.0-0.9 \mathrm{Ga}$. This accretionary mobile belt, recently termed as the Rayner-Eastern Ghats (R-EG) belt (Morrissey et al., 2015) holds key to the proposed IndoAntarctic correlation in the global geodynamic perspective of the Neoproterozoic Rodinia supercontinent (Dasgupta et al., 2013, 2017; Bose and Dasgupta, 2018).

Over the last thirty years, EGB has gained much attention in geology fraternity because it provided an opportunity to know about the physical and chemical evolution 
of the lower crust during UHT metamorphism (Harley, 2004). After the discovery of this extreme condition of regional-scale metamorphism from the EGB, numerous research publications focusing metamorphic petrology, geochronology, and geodynamic modeling have emerged indicating the EGB as a collage of different crustal blocks with independent evolutionary history, but mostly from the southern and the central parts of this belt. In particular, the central part of the EGB and the Rayner Complex of East Antarctica remained in the focus of research, and detailed structural, petrological, geochemical, and isotopic studies are done on the granulites exposed in these areas (Halpin et al., 2007; Bose et al., 2011; Das et al., 2011a; Korhonen et al., 2013; Morrissey et al., 2015, 2016). Except for some key areas, the geological histories of the northern and northwestern parts, however, remained unknown which hinders understanding the geological evolution of the EGB in entirety. In this contribution, we offer a compilation of recent data from the areas of northern and northwestern EGB which remains a crucial missing link for a long time. An updated review is made here collating metamorphic, structural and geochronological records in the context of Indo-Antarctic correlation.

\section{GEOLOGICAL SETTING}

The EGB is a NE-SW trending Meso-Neoproterozoic orogenic belt located at the eastern part of peninsular India (Fig. 1). This belt is bordered by cratonic landmasses both in the northern and the western parts. These cratonic landmasses include the Singhbhum Craton (SC) in the northern part and the Bastar Craton (BC) and the Dharwar Craton (DC) in the western part. Of these, the SC and the $\mathrm{BC}$ have contacts respectively with the northern and the northwestern parts of the EGB. Major geological events and the geochronological constraints of the $\mathrm{BC}$ and $\mathrm{SC}$ are discussed below.

The $\mathrm{BC}$ is one of the Archean cratons of the Indian Shield and the Archean basement gneisses of this craton have been dated to be $~ 3.51-3.56 \mathrm{Ga}$ (Sarkar et al., 1993; Ghosh, 2004; Rajesh et al., 2009). These basement gneisses are reported to be intruded by granitic rocks $(\sim 2.5 \mathrm{Ga})$ that are mostly unmetamorphosed and undeformed in nature (Sarkar et al. 1993; Stein et al., 2004; Rajesh et al., 2009). This craton also consists of metagabbroic and basaltic rocks with intercalated andalusite-, chloritoid- and fibrolite schists, sillimanite quartzite, cordierite-bearing rocks and banded iron formation (BIF) (Ramakrishnan,

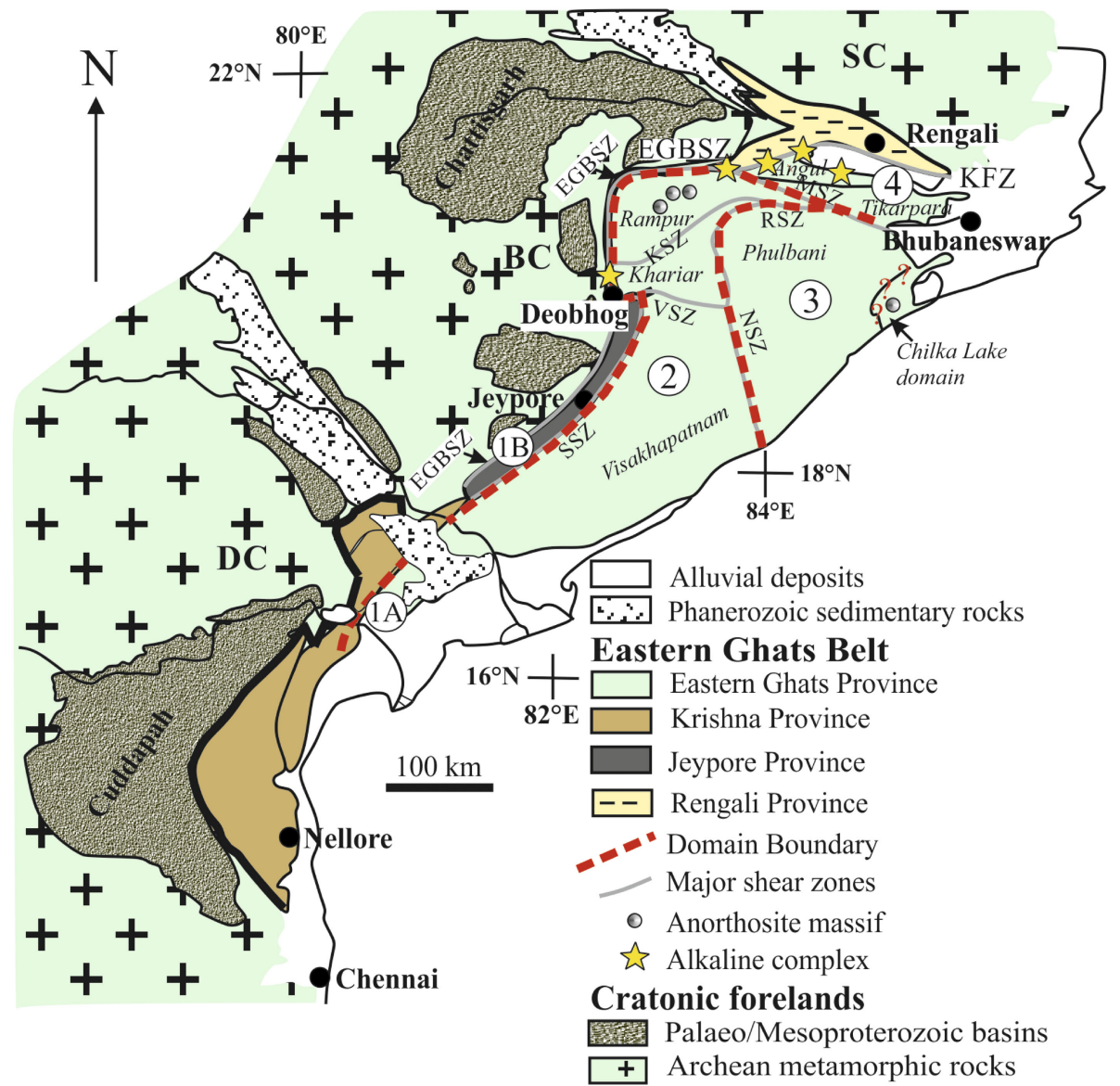

Figure 1. Geological map of the Eastern Ghats Belt with crustal provinces (after Dobmeier and Raith, 2003) and domains (after Rickers et al., 2001). Major shear zones and domain boundaries are also shown. Domains are marked by numbers in circle. EGBSZ, Eastern Ghats Boundary Shear Zone; MSZ, Mahanadi Shear Zone; RSZ, Ranipathar Shear Zone; KSZ, Koraput Shear Zone; SSZ, Sileru Shear Zone; VSZ, Vamshadhara Shear Zone; NSZ, Nagavalli Shear Zone; SC, Singhbhum Craton; BC, Bastar Craton; DC, Dharwar Craton. 
1990; Ramakrishnan and Vaidyanadhan, 2010). In addition to this, small isolated outcrops of greenstone belt sequences are also reported in this craton near Bastar, Jeypore, Bijapur, Sonepur, and Sonakhan areas. Proterozoic sedimentary basins namely Chhattisgarh, Khariar, Ampani, Sukma, and Indravati occupy a major portion of the eastern part of this craton and geochronological studies of interbedded tuff layers from basal parts of the Chhattisgarh and Khariar basin successions suggest basin opening at 1.5-1.45 Ga (Patranabis-Deb et al., 2007; Das et al., 2009; Das et al., 2011b; Das et al., 2015). The contact of the $\mathrm{BC}$ and the EGB is marked by Eastern Ghats Boundary Shear Zone (EGBSZ) (Fig. 1), along which the granulite facies rocks of the latter are interpreted to be thrusted over the cratonic rocks (discussed later in detail).

The SC is a Paleoarchean granite-greenstone terrane and dominantly composed of $\sim 3.5-3.3 \mathrm{Ga}$ lithological units which include the Older Metamorphic Tonalite Gneiss (OMTG) (Upadhyay et al., 2014; Olierook et al., 2019 and references therein); the Older Metamorphic Group (OMG, Nelson et al., 2014), and Iron Ore Group (IOG) (Mukhopadhyay et al., 2008). The SC is flanked by the Meso- to Paleoarchean Rengali Province (RP) at the south which records the southward growth of the craton through complex tectonothermal evolution during $\sim$ 3.0-2.5 Ga (Bose et al., 2015; Bose et al., 2016a). The RP also separates the Singhbhum craton from the southerly placed EGB (Fig. 1) and the contact is marked by Kerajang Fault Zone (KFZ, Yamamoto et al., 2017). The KFZ was interpreted to form at the early Paleozoic time during transpressional deformation at the southern margin of RP and marks the accretion of EGB with the greater Indian landmass (Ghosh et al., 2016).

EGB, bounded by the two above-mentioned older cratonic blocks is subdivided into four longitudinal lithological zones, viz. the Western and Eastern Khondalite Zones, Central Migmatite Zone, and the Western Charnockite Zone by Ramakrishnan et al. (1998). Ramakrishnan et al. (1998) further identified a Transition Zone separating the EGB from the adjacent BC. This classification is based solely on the lithological disposition of the rocks of the EGB without considering the metamorphic and geochronological history of the belt. Later studies identified several inconsistencies in this longitudinal classification including the status of the Transition Zone (reviewed in Dasgupta and Sengupta, 2003). Based on $\mathrm{Sm}-\mathrm{Nd}, \mathrm{Rb}-\mathrm{Sr}$ whole rock data, and $\mathrm{Pb}-\mathrm{Pb}$ isotopic data of feldspars from ortho- and paragneissic rocks, Rickers et al. (2001) proposed that EGB is a collage of four discrete isotopic domains with contrasting protolith ages. These isotopic domains are named as domains 1 (1A and 1B), 2, 3 and 4 (Fig. 1). Dobmeier and Raith
(2003) used the isotopic data of Rickers et al. (2001) and clubbed with the existing metamorphic, structural and geochronological data of the entire EGB to propose the province- and domain-based classification of the belt (Fig. 1). Accordingly, the EGB is an amalgamation of four major crustal provinces, each having discrete geological histories. These crustal provinces are the Krishna Province, the Jeypore Province, the Eastern Ghats Province (EGP), and the Rengali Province, positioned south to north, respectively. The present study is concerned only about the EGP and readers interested to know about the other provinces are referred to Dasgupta et al. (2017) and Bose and Dasgupta (2018).

According to Dobmeier and Raith (2003), the Visakhapatnam, Phulbani, Rampur, Khariar, Tikarpara, Angul, and Chilka Lake domains constitute the EGP. Except for the Visakhapatnam domain, all the other domains occupy the dominant portion of the northern and the northwestern part of the EGB. It is additionally notable that without constraining the structural characters, the shear zones dissecting the above domains were considered as the domain boundaries by the above authors. These shear zones include Mahanadi Shear Zone (MSZ) and Ranipathar Shear Zone (RSZ) at the north and Nagavalli-Vamshadhara Shear zone (NVSZ) at the central part of the EGP. Recently, Ganguly et al. $(2017,2018)$ pointed out the problem of the domain-based classification of the EGP and concluded that the shear zones should not be considered as domain boundaries. Accordingly, the individual 'domains' are henceforth termed as 'areas' of which the Visakhapatnam is most well-constrained in terms of petrological and geochronological aspects (Dasgupta et al., 2017 and references therein). The geological history of the Chilka Lake area is also well known (Sen et al., 1995; Dasgupta and Sengupta, 2003; Chatterjee et al. 2008; Bose et al., 2016b), but due to the differences in petrological and geochronological characters with other areas of the EGP, it is considered as a separate domain in the present review. The Phulbani area remained unexplored for a long time until recent works of Ganguly et al. (2017, 2018). Studies from the other areas which include the Rampur, Khariar, Tikarpara, and Angul (Sarkar et al., 2007) are also scanty. It is therefore imperative to know the geological evolution of these areas for a holistic understanding of the tectonic evolution of the northern and northeastern part of the EGB. In the present study published literature is collated to make a review of the tectonometamorphic and tectonothermal evolutions of the portion of the EGB mentioned above. This will help to point out the key issues which should be addressed in future studies. The petrological, geochronological, and deformation histories of these areas are combined in the fol- 


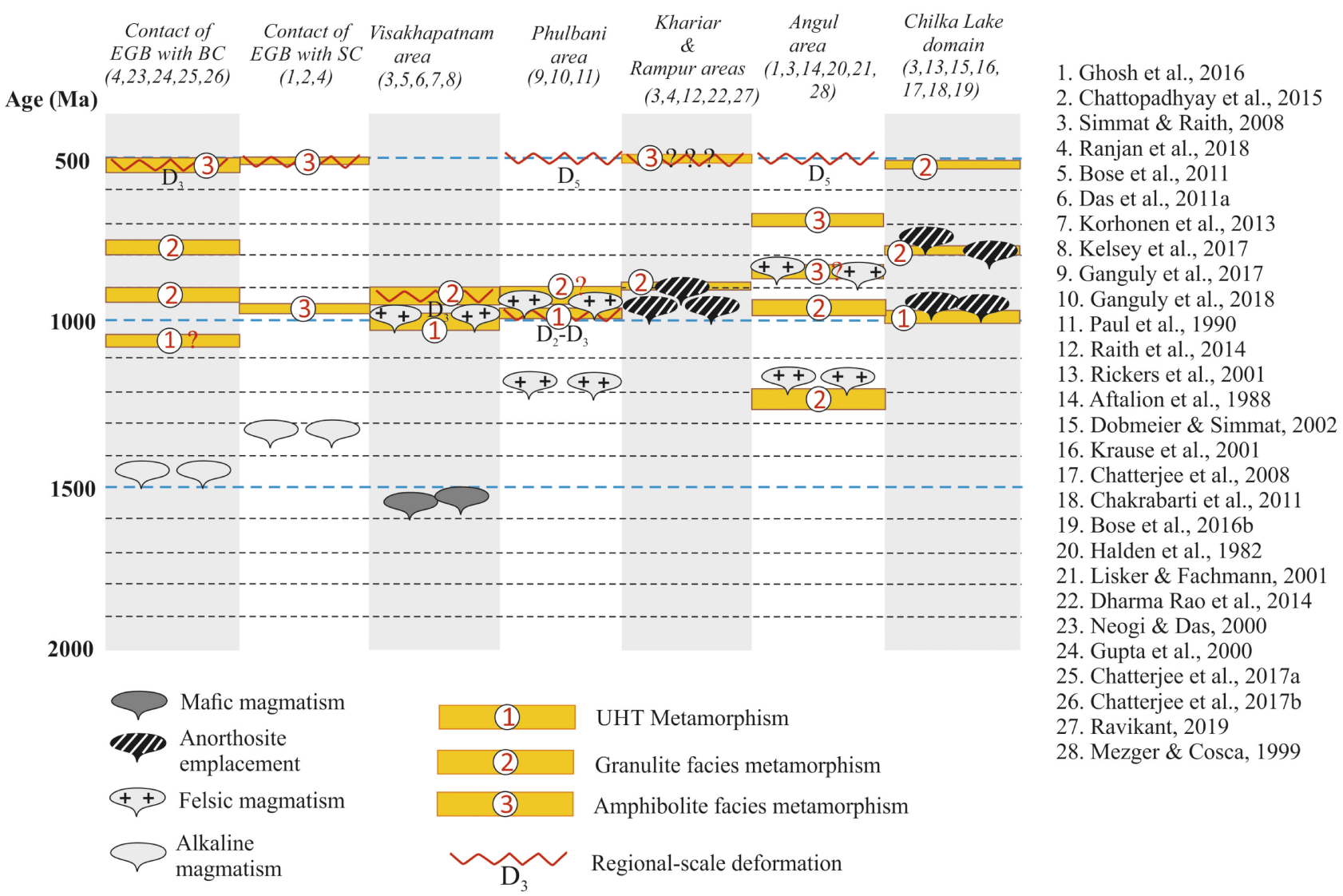

Figure 2. Schematic diagram showing the timings of metamorphism, deformation and magmatism in different areas of the northern and the northwestern EGB. Please note that Chilka Lake is considered a separate domain due to the differences in petrological and geochronological characters with other areas of the EGP.

lowing sections and summarized in Figure 2.

\section{GEOLOGICAL EVOLUTION OF THE NORTHERN AND THE NORTHWESTERN EGB}

\section{Chilka Lake domain}

Sen et al. (1995) first documented a multi-stage tectonothermal evolution with a peak UHT $\left(12 \mathrm{kbar}, 1000{ }^{\circ} \mathrm{C}\right)$ metamorphism from the Chilka Lake domain. Raith et al. (2007) and Sengupta et al. (2008) later on refined the data of Sen et al. (1995) and suggested that the pressure was much lower $\sim 7.5 \mathrm{kbar}$. Later studies suggested a multistage (at least four metamorphic and deformation events) evolution through transpressional tectonics for this domain that started at $\sim 0.99 \mathrm{Ga}$ with the UHT metamorphism (900-950 $\left.{ }^{\circ} \mathrm{C}, 8.5-9.0 \mathrm{kbar}\right)$ along a speculated clockwise $P-T$ path (Das et al., 2012; Bose et al., 2016b) (Fig. 3a). This was followed by decompression up to $\sim 7 \mathrm{kbar}$ and $800^{\circ} \mathrm{C}$ and corresponds to zircon and monazite growth at $0.78 \mathrm{Ga}$ in aluminous granulite. The $\sim 0.75 \mathrm{Ga}\left(700^{\circ} \mathrm{C}, 6 \mathrm{kbar}\right)$ and $0.52 \mathrm{Ga}\left(800^{\circ} \mathrm{C}, 6 \mathrm{kbar}\right)$ metamorphic events in the Chilka Lake domain involve cooling of the granulitic rocks to produce biotite- bearing mineral assemblage and subsequent heating which resulted in incipient growth of orthopyroxene-cordierite-Kfeldspar, respectively. The $\sim 0.78 \mathrm{Ga}$ and $\sim 0.52 \mathrm{Ga}$ events have been correlated respectively with the break-up of Rodinia and the thermal overprinting during Pan-African metamorphism. Considering the similarities in styles of metamorphism, Bose et al. (2016b) proposed that the Chilka Lake domain was attached to the Prydz Bay, East Antarctica and became separated at $0.78 \mathrm{Ga}$ during breakup of Rodinia which was followed by $0.52 \mathrm{Ga}$ event when it became united with the greater Indian landmass as a part of east Gondwana. Massif-type anorthosite bodies are also reported from the Chilka Lake domain and have been variably dated as $\sim 0.79 \mathrm{Ga}$ (Krause et al., 2001), $\sim 0.85$ Ga (Chakrabarti et al., 2011), and $\sim 0.98 \mathrm{Ga}$ (Chatterjee et al., 2008).

\section{Phulbani area}

This area occupies a major portion of the northern EGB but 

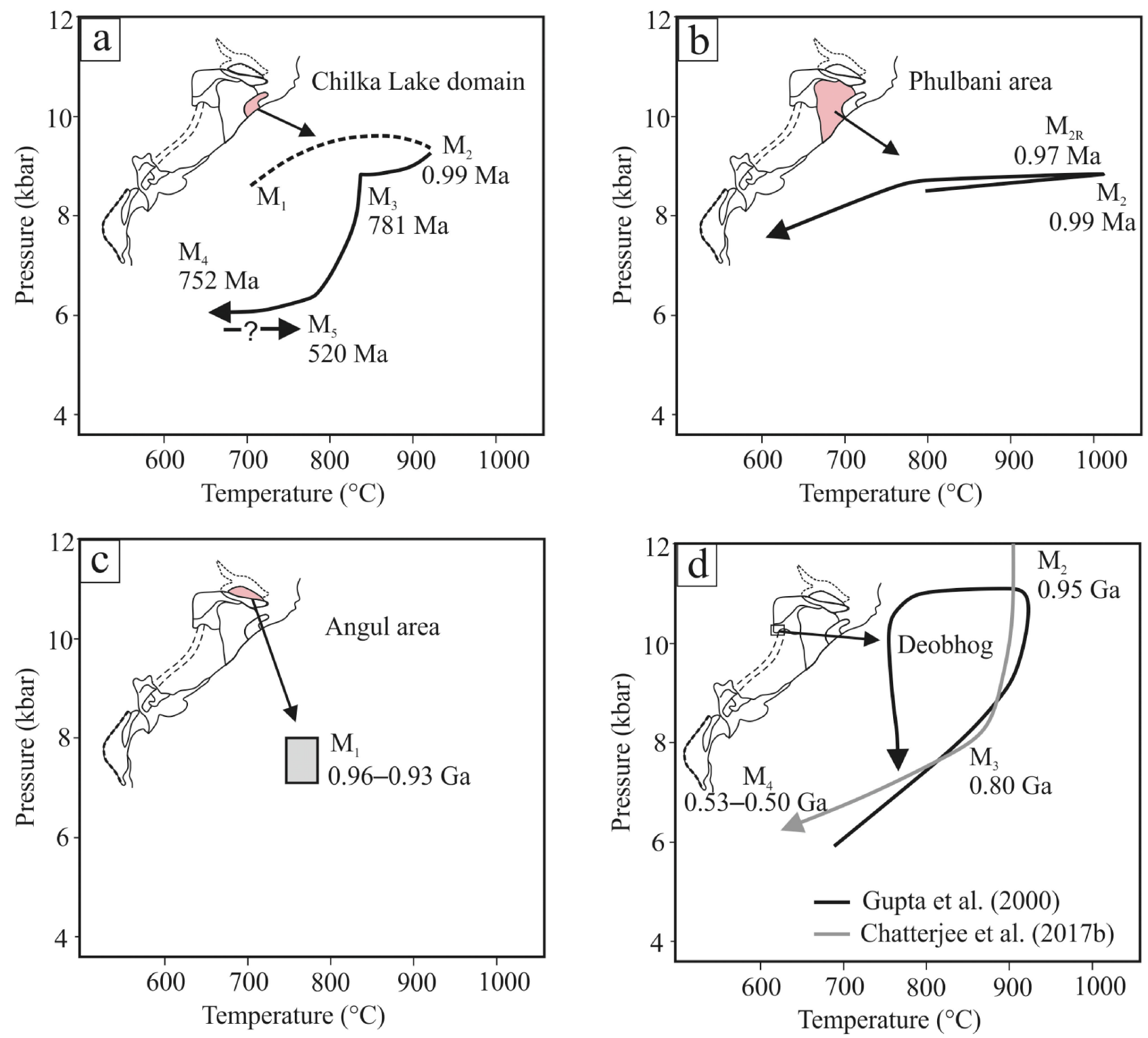

Figure 3. $P-T$ paths and metamorphic episodes of (a) Chilka Lake domain, (b) Phulbani area, (c) Angul area, and (d) contact of northwestern EGB with BC (Deobhog area).

remained mostly unexplored barring sporadic geochronological data from charnockitic and metapelitic rocks (Paul et al., 1990; Upadhyay et al., 2009). Based on the textural study, thermobarometry and phase diagram modeling, recently Ganguly et al. (2017) suggested that the area also experienced peak UHT condition $\left(1000^{\circ} \mathrm{C}, \sim 8 \mathrm{kbar}\right)$ similar to the Chilka Lake domain. Texturally constrained monazite ages obtained from aluminous granulite exposed in the Phulbani area, additionally, suggest that the UHT metamorphism occurred at $\sim 0.99 \mathrm{Ga}$ (Ganguly et al., 2018). It is notable that unlike the possible clockwise $P$ $T$ path of the Chilka Lake domain, the Phulbani area was interpreted to evolve through an almost isobaric prograde path (Fig. 3b) as evidenced by the aluminous granulite samples where spinel + quartz-bearing mineral assemblages developed during UHT metamorphism. It was subsequently followed by a cooling dominated retrograde path and represented by coronitic and symplectic growth of garnet and/or quartz in aluminous granulite, calc-silicate granulite and charnockitic rocks. From the oscillatory zoned monazite domains of felsic gneiss, the age of such cooling was estimated to be $\sim 0.97 \mathrm{Ga}$ (Ganguly et al., 2018). Interestingly, such a cooling episode coincides with the charnockite magmatism of $\sim 0.97 \mathrm{Ga}$ in the above area. The Phulbani area additionally documents granitic magmatism preceding UHT metamorphism. Such magmatic rocks are now preserved as felsic gneiss and probably formed the basement of the EGP. Based on zircon U-Pb dating, the 
crystallization age of such granitic rock was estimated to be $1173 \pm 12 \mathrm{Ma}$.

Although limited geochronological data related to the granulite facies metamorphism of $\sim 0.95-0.90$ Ga are available from the northern EGB, zircon and monazite growth during this time-frame in the UHT metamorphosed rocks of the Phulbani area has already been reported by Ganguly et al. (2018). These metamorphic and geochronological histories are similar to those from the Visakhapatnam area (Das et al., 2011a; Bose et al., 2011). The metamorphic and magmatic activities spanning 1.0-0.9 Ga in the Phulbani area, therefore, appear to be similar to the adjacent Visakhapatnam area indicating the contiguous nature of these two areas during the above time-frame.

The Phulbani area additionally bears a unique character preserving the fabric developed during UHT metamorphism. Trending WNW-ESE, this fabric is designated to be a composite $S_{2} / S_{3}$ gneissic fabric, developed during successive $\mathrm{D}_{2}-\mathrm{D}_{3}$ deformation phases. The following deformation phase $\left(\mathrm{D}_{4}\right)$, occurred in local-scale to give rise to N-S trending ductile shear zones and an NW-SE trending gneissic fabric. The last deformation phase $\left(\mathrm{D}_{5}\right)$, however, appears to be responsible for the present-day structural architecture of the Phulbani area and developed a major ductile shear zone which is named Ranipathar Shear Zone (RSZ). Deformation $\left(\mathrm{D}_{5}\right)$ at RSZ transposed the earlier fabrics to develop an almost E-W trending mylonitic foliation $\left(\mathrm{S}_{5 \mathrm{~S}}\right)$. Based on ${ }^{40} \mathrm{Ar} /{ }^{39} \mathrm{Ar}$ age of biotite present in augen gneiss, Crowe et al. (2001) suggested that ductile shearing at RSZ possibly occurred at $\sim 0.5 \mathrm{Ga}$.

\section{Angul area}

Unlike the Chilka Lake domain and the Phulbani area, the Angul area does not preserve evidence of UHT metamorphism. A granulite facies metamorphic event $\left(\mathrm{M}_{1}\right.$, Fig. 3c) is documented from the above area by Sarkar et al. (2007). Thermobaric condition of this metamorphism reached $>750{ }^{\circ} \mathrm{C}, 7-8 \mathrm{kbar}$, calculated respectively from the scapolite-calcite-plagioclase-bearing calc-silicate granulites and garnet-sillimanite gneisses. According to Mezger and Cosca (1999), the metamorphic event occurred at $\sim 0.96-0.93 \mathrm{Ga}$. Simmat and Raith (2008), however, documented $\sim 1.26-1.20 \mathrm{Ga}$ and $\sim 0.98-0.97$ Ga chemical ages from monazite grains of metapelitic rocks of the Angul area. These age clusters are assigned respectively to an early granulite facies metamorphism and subsequent high-temperature tectono-metamorphic event. Although $\sim 1.26-1.20 \mathrm{Ga}$ age has not been documented by other workers, the $\sim 0.98-0.97$ Ga age closely matches with the TIMS U-Pb monazite ages clustering between $\sim 0.97-0.95$ Ga (Aftalion et al., 1988; Mezger and Cosca, 1999). From the Angul area, Aftalion et al. (1988) moreover documented $\sim 1.16 \mathrm{Ga}$ age from zircon grains of granitic rocks and interpreted this as the age of the crystallization of the basement.

Based on detailed structural mapping of the granulite facies rocks, Sarkar et al. (2007) proposed that the above area experienced five deformation phases $\left(\mathrm{D}_{1^{-}}\right.$ $\left.D_{5}\right)$ of which the last deformation phase $\left(D_{5}\right)$ obliterated most evidence of earlier deformations. Accordingly, this last deformation phase $\left(\mathrm{D}_{5} / \mathrm{S}_{5}\right.$ fabric $)$ was responsible for WNW-ESE trending shear planes that caused considerable reorientation of earlier fabrics and corresponds to late-stage thrusting with top-to-the-south shear sense. The $\mathrm{S}_{5}$ fabric was additionally correlated with the WNW trending amphibolite facies fabric in the Mesoarchean Rengali Province and interpreted to have resulted during docking of the two terranes. Based on the previously available data (hornblende ${ }^{40} \mathrm{Ar} /{ }^{39} \mathrm{Ar}$ cooling ages of Crowe et al., 2001, 2003), Sarkar et al. (2007) suggested the age of the $\mathrm{D}_{5}$ could be $\sim 0.70 \mathrm{Ga}$. Recently, Ghosh et al. (2016) proposed that the Rengali Province experienced a major transpressional deformation episode during $0.50-0.52 \mathrm{Ga}$. The Angul area of EGP possibly acted as the rigid indenter during this time.

\section{Rampur and Khariar areas}

Several occurrences of massif-type anorthosite bodies are reported from the Khariar and Rampur areas which are namely Bolangir, Turkel, and Jugsaipatna anorthosite complexes. These anorthosite complexes resulted by crystallization of anorthositic magma at $\sim 0.98-0.93 \mathrm{Ga}$ (Krause et al., 2001; Raith et al., 2014; Dharma Rao et al., 2014) and subsequently metamorphosed during $\sim 0.90$ $0.88 \mathrm{Ga}$. Structural analyses of Bolangir anorthosite complex (Nasipuri and Bhadra, 2013) moreover suggest that the emplacement of anorthosite pluton was syn-tectonic with respect to the regionally pervasive $\mathrm{D}_{3}$ deformation $(\sim 1.0-0.9 \mathrm{Ga})$. Late Neoproterozoic to early Paleozoic zircon $\mathrm{U}-\mathrm{Pb}$ ages from the above complexes additionally indicate thrusting of Khariar and Rampur areas over westerly placed BC during the Pan-African event (Raith et al., 2014 and references therein, Ravikant, 2019). Excepting the anorthosite emplacement, the geological evolution of the rock suite exposed in the Khariar and the Rampur areas covering a vast area of the northwestern part of the EGB is unknown in the existing literature.

\section{Contact of the northern and the northwestern EGB with the $\mathrm{BC} / \mathrm{SC}$}

The contact of the northwestern EGB and the adjoining 
$\mathrm{BC}$ is marked by the EGBSZ. This contact is composed of granite gneiss, garnet-sillimanite gneiss, high $\mathrm{Mg}-\mathrm{Al}$ granulite, and charnockite rocks. The Khariar alkaline complex is also located here along $\sim 30 \mathrm{~km}$ long NESW trending sinuous belt. The complex is dominated by nepheline syenite in the core and syenite along the marginal zones. The metamorphic condition of the contact is well-constrained from the Deobhog and the surrounding areas which were interpreted to be affected by UHT metamorphism along an anticlockwise $P-T$ path (Fig. 3d). This was confirmed by the presence of garnet-orthopyroxenebearing leucosomes and orthopyroxene-clinopyroxeneplagioclase assemblage in mafic granulites and sapphirine-cordierite-orthopyroxene in high $\mathrm{Mg}$ - $\mathrm{Al}$ granulites $\left(\geq 900{ }^{\circ} \mathrm{C}\right.$ and $9.5-10$ kbar by Gupta et al., 2000; Neogi and Das, 2000). Such a $P-T$ condition was further refined to be $\sim 900{ }^{\circ} \mathrm{C}$ and $10-11 \mathrm{kbar}\left(\mathrm{M}_{2}\right.$ of Chatterjee et al., 2017b; Fig. 3d). Slightly lower peak $P-T$ condition was estimated by Bhattacharya (2004), Bhadra et al. (2007), and Das et al. (2008) as $\sim 800-850{ }^{\circ} \mathrm{C}$ and $\sim 8-9$ kbar. Gupta et al. (2000) and Bhadra et al. (2004), moreover, proposed that such $P-T$ condition resulted during the thrusting of 'hot' deep-crustal EGB on 'cold' shallowto mid-crustal BC. Subsequently, the granulites were exhumed by the thrusting which resulted in the formation of decompression textures over the peak metamorphic mineral assemblages. The retrograde $P-T$ condition was estimated to be $\sim 750-850{ }^{\circ} \mathrm{C}$ and $\sim 6-7 \mathrm{kbar}$ from the orthopyroxene-plagioclase symplectites (Gupta et al., 2000; Neogi and Das, 2000; Chatterjee et al., 2017a). The development of the coronal garnet during cooling and the formation of hydrous minerals (e.g., hornblende and biotite) from pyroxene grains during concomitant $\mathrm{H}_{2} \mathrm{O}$ influx also indicate the retrograde $P-T$ condition (Chatterjee et al., 2017a, 2017b). Contrary to this interpretation of symplectite formation due to (isothermal) decompression, Das et al. (2008) opined that the orthopyroxene-plagioclase symplectite occurred due to postthrust heating.

Based on $\mathrm{U}-\mathrm{Pb}$ zircon dating, the emplacement age of the alkaline rocks of the Khariar alkaline complex was determined to be $\sim 1.47 \mathrm{Ga}$ (Upadhyay et al., 2006; Ranjan et al., 2018). Simmat and Raith (2008) obtained texturally constrained monazite ages spanning $\sim 1.06-0.90$ Ga of which $\sim 1.06 \mathrm{Ga}$ was interpreted to represent the age of the UHT metamorphism in the Deobhog area. The latter age is shown by monazite grains present as inclusions in porphyroblastic phases of UHT metamorphosed high $\mathrm{Mg}-\mathrm{Al}$ granulite. Chatterjee et al. (2017b) reported growth of monazite and zircon at $\sim 0.95-0.90 \mathrm{Ga}$ from charnockitic rocks from the nearby areas that corresponds to granulite facies metamorphism $\left(\mathrm{M}_{2}\right)$, overprinted by two younger metamorphic events $\left(\mathrm{M}_{3}\right.$ and $\left.\mathrm{M}_{4}\right)$ spanning $\sim 0.80-0.75$ and $0.53-0.50 \mathrm{Ga}$. Of these, the $\mathrm{M}_{4}$ appears to be dominant at the cratonic contact zone rocks where $\sim 0.95-0.90 \mathrm{Ga}$ is totally absent. Based on this, Chatterjee et al. (2017b) proposed an age zonation which is characterized by the presence of $\sim 0.95-0.90$ Ga granulite facies metamorphism in the interior part of the EGB and the 0.53-0.50 Ga event, overprinting the granulite facies metamorphism, at the zone bordering the craton. This latter event marks the cratonization vis-à-vis thrusting of the EGP with/over the greater Indian landmass which is documented in the cratonic rocks by the development of zircon overgrowths on the $\sim 2.4 \mathrm{Ga}$ zircon cores. This thrusting event signifies the final amalgamation of India and East Antarctica that possibly continued up to $\sim 0.49$ $\mathrm{Ga}$ and now preserved as youngest monazite age in syndeformational sedimentary rocks interpreted to be developed in a foreland basin (Chatterjee et al., 2017b).

The unequivocal evidence concerned to thrusting of EGB granulites over the $\mathrm{BC}$ was constrained by several structural studies from Deobhog-Dharamgarh transect (Gupta et al., 2000), Bhawanipatna-Sinapalli-Khariar transect (Das et al., 2008), Khariar (Biswal et al., 2007), and Parla (Bhadra et al., 2004; Chatterjee et al., 2017a). According to these workers, a regional-scale penetrative foliation $\left(\mathrm{S}_{3}\right)$ interpreted to develop during a pervasive $\mathrm{D}_{3}$ deformation event, defines the structural architecture of the contact zone (Gupta et al., 2000; Bhadra et al., 2004). The $S_{3}$ fabric was developed when mutually subparallel $S_{1}$ and $S_{2}$ fabrics were folded into a set of open to tight folds with NE-SW and ENE-WSW trending axial plane (Das et al., 2008). Several kinematic markers, such as the asymmetric sigmoidal augen and intrafolial folds, suggest that $S_{3}$ is a shear fabric and resulted during the thrust-related tectonics (Chatterjee et al., 2017a). The westward asymmetricity of the kinematic markers and westward disruption of the $S_{1}$ fabric along the $S_{3}$ suggest a top-to-the-west sense of thrusting (Chatterjee et al., 2017a). Near the EGB-BC contact, the $S_{3}$ fabric is striking almost $\mathrm{N}-\mathrm{S}$ and moderate- to low-dipping towards the east. This $\mathrm{S}_{3}$ fabric, on the other hand, striking NW-SE with steeper dip ranges between $60-70^{\circ}$ towards the eastern side of the orogenic interior (Chatterjee et al., 2017a) suggesting that the structural imprints of the thrust-related tectonics gradually weakened towards the eastern side of the EGB-BC contact.

The contact of the northern EGB and the RP is characterized by a linear chain of alkaline complexes (Fig. 1) which are namely Chhatabar, Rairakhol, Lodhajhari, Baradangua, and Kamakhyanagar. These alkaline complexes consist of pegmatitic nepheline syenites, syenites, and alkali feldspar syenite rocks. Zircon U-Pb dating of these 
rocks indicates that the alkaline rocks of the above complexes emplaced during 1.37-1.32 Ga (Ranjan et al., 2018). Details of the metamorphic character and the structural evolution of the RP are not discussed here as it is presented in Ghosh and Bose (this volume).

\section{DISCUSSION}

The key issues that came out from the above synthesis are discussed below and schematic diagrams in the context of the tectonic evolution of the northern and the northwestern EGB are presented in Figure 4. This will give a brief idea of the geological history of the presently reviewed portion of the EGB.

Geochronological records from the EGP over the last three decades suggest that the majority of the ages vary within the range of $\sim 1.0-0.90 \mathrm{Ga}$, which is interpreted to be the period of high-grade metamorphism, magmatism, and associated deformation. A recent study of Ranjan et al. (2018), on the contrary, suggests that the tectonic activity in the EGP started at much earlier through alkaline magmatism at the contacts of the EGB and the adjoining cratons. Having crystallization age of $\sim 1.47-1.32 \mathrm{Ga}$ in the northern and the northwestern EGB, these magmatic rocks are now preserved as nepheline syenite and syenite bodies and provide a window to constrain the thermal history occurred at the margin of the Greater Indian Landmass (Bose and Dasgupta, 2018). Such magmatism is interpreted to be resulted during rifting of the supercontinent Columbia (Ranjan et al., 2018) and followed by sedimentation during the period of 1.4-1.2 Ga (Upadhyay et al., 2009), indicating about the time-frame of the stability of such rift basin. These magmatic pulses were followed by granitic magmatism of $\sim 1.17 \mathrm{Ga}$ which is documented from the Phulbani area (Ganguly et al., 2018). Similarly, the Angul area also experienced granitic magmatism at $\sim 1.16 \mathrm{Ga}$ (Aftalion et al., 1988), and these two collectively suggest the crystallization age of the probable basement of the EGP. Recently, Das et al. (2017) also documented the age of $\sim 1.17$ Ga from monazite grains included within hemo-ilmenite, Ti-hematite and spinel grains present in aluminous granulite exposed at the Visakhapatnam area and inferred this as the age of UHT metamorphism. On a similar note, Simmat and Raith (2008) also obtained $\sim 1.26-1.20$ Ga age from monazite grains included within porphyroblastic garnet and interior portions of matrix monazite grains present in metapelitic rocks of the Angul area and suggested this as the age of an early granulite facies metamorphism. Before considering this event as an early granulite facies or UHT metamorphism in the EGP, one must rule out the possibility that such monazite ages are inherited and sourced from the granitic basement. The absence of such a basement at the Visakhapatnam area may result from intensive reworking at the orogen interior. This granitic magmatism could be linked with the alkaline magmatism reported by Ranjan et al. (2018), but detailed geochemical investigations of the basement are required to unravel the actual tectonic setting which will definitely shed some light on the early magmatic history of the EGP.

The major metamorphic episode which affected the EGP is UHT metamorphism which was interpreted to occur during $\sim 1.03-0.99 \mathrm{Ga}$ in the Visakhapatnam area (Bose et al., 2011; Das et al., 2011a) along an anticlockwise $P-T$ path with complex melt-fluid-rock interaction (Bose et al., 2008). Based on the available information, Dasgupta et al. $(2013,2017)$ proposed a tectonic model explaining UHT metamorphism in the EGP (involving the Visakhapatnam area). According to this model, an anomalously hot orogen developed regionally by mantle heat input, possibly as a result of lithospheric-scale thinning and asthenospheric upwelling during $\sim 1.03-0.99 \mathrm{Ga}$. This appears to be true also for the Phulbani area which was affected by UHT metamorphism along a near-isobaric prograde and retrograde $P-T$ path at $\sim 0.99$ Ga (Fig. 3b) (Ganguly et al., 2017, 2018). The similarities in the metamorphic and geochronological data from both the above areas, therefore, indicate that these two areas evolved together and possibly were attached to each other during the proposed time-frame. A voluminous amount of granitic and charnockite magmatism during $\sim 0.98-0.96 \mathrm{Ga}$ in both the areas additionally suggest about the continuation of deep-crustal thermal perturbation. Interestingly, the Rayner Complex of East Antarctica also experienced similar charnockitic (Mawson Charnockite) and granitic intrusion during this time and marks the onset of accretion of the EGP and the Rayner Complex (R-EG orogeny of Morrissey et al., 2015). The status of the Chilka Lake domain becomes important in this context as this area was also affected by $\sim 0.99 \mathrm{Ga}$ UHT metamorphism albeit along a possible clockwise $P-T$ path (Fig. 3a), unlike the Visakhapatnam and the Phulbani areas. Differences in the $P-T$ path in these two areas led Bose et al. (2016b) to suggest that the Chilka Lake domain was not attached to the EGP during this time. It is noteworthy that the Deobhog area of the northwestern EGB was also affected by UHT metamorphism (Fig. 3d) (Gupta et al., 2000; Neogi and Das, 2000) and structural analyses of Gupta et al. (2000) suggests that this metamorphic episode corresponds to thrusting of the EGB rocks over the gneissic rocks of the BC. If the UHT metamorphism and thrusting episode are considered to have occurred at 0.55-0.50 Ga (Chatterjee et al., 2017b), then the UHT metamorphism of $\sim 1.06 \mathrm{Ga}$ of Simmat and Raith (2008) 
Rifting during Columbia break-up at ca. 1.47-1.32 Ga

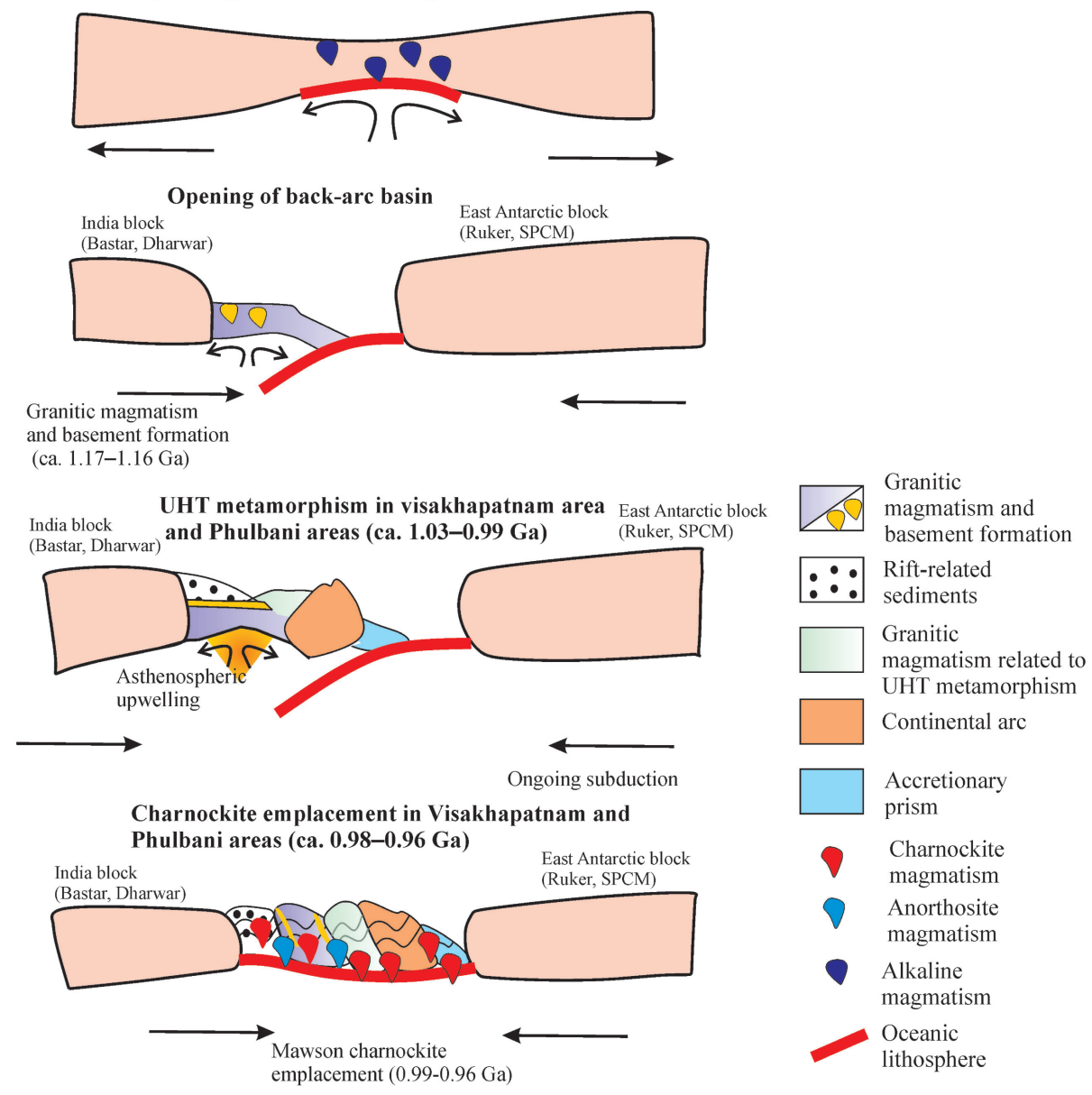

Collision and final amalgamation of Visakhapatnam, Phulbani and Rayner Complex (ca. 0.95-0.90 Ga)

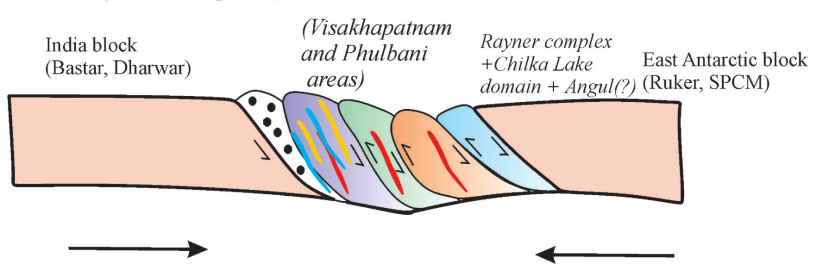

Rifting at ca. $0.78 \mathrm{Ga}$

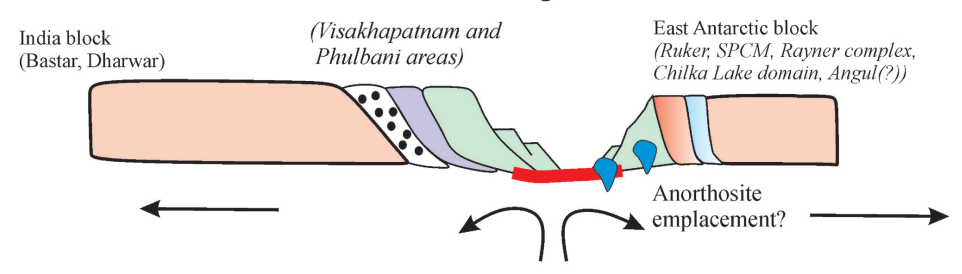

Formation of east Gondwana at ca. $0.55-0.50 \mathrm{Ga}$

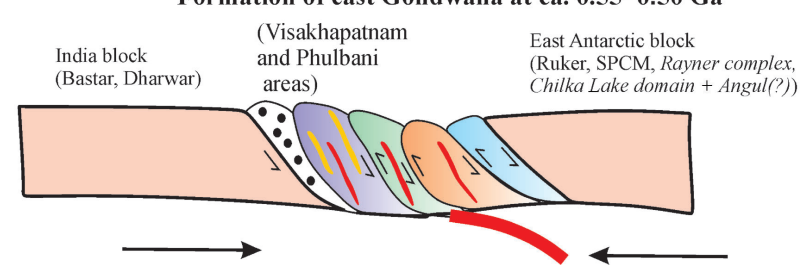

Figure 4. Schematic diagrams showing the tectonic evolution of the northern and the northwestern EGB (modified after Dasgupta et al., 2013 and Dasgupta et al., 2017) 
from this area becomes problematic. Clearly, a more detailed petrochronological study is required to resolve this issue.

Development of massif-type anorthosite complexes of the northern EGP namely the Bolangir, Turkel, and Jugsaipatna closely followed the UHT event and were interpreted to form at $0.98-0.93$ Ga during R-EG accretion (Raith et al., 2014, Dharma Rao et al., 2014). While Dobmeier (2006) and Raith et al. (2014) considered the crustal tongue melting model of Duchesne et al. (1999) to be appropriate for the development of massif anorthosite complexes of the Bolangir and Turkel, Dharma Rao et al. (2014) expressed a different opinion regarding the same. Based on the work on Jugsaipatna Anorthosite Complex, the latter workers proposed that the anorthositic magma emplaced in a slab-breakoff setting accompanied by upwelling of the asthenospheric mantle through the opening slab-window. In spite of the existence of such contrasting opinions regarding the development of the massif anorthosite complexes mentioned above, the geochronological data suggest that all the complexes emplaced in a similar time-frame $(0.98-0.93 \mathrm{Ga})$. This appears to be contrasting when compared to the massif anorthosite complex of the Chilka Lake domain which has been variably dated as $\sim 0.79 \mathrm{Ga}$ (Krause et al., 2001), $\sim 0.85 \mathrm{Ga}$ (Chakrabarti et al., 2011), and $\sim 0.98 \mathrm{Ga}$ (Chatterjee et al., 2008). The above disparity could either be due to separate pulses of anorthositic magmatism spanning 0.98-0.79 Ga or problems in isotopic systematics adopted by the different workers. The actual reason is still unknown and should be addressed in future studies.

The granulite-grade reworking along a clockwise $P-T$ path occurred in the Visakhapatnam domain (Bose et al., 2011; Das et al., 2011a) area during $\sim 0.95-0.90 \mathrm{Ga}$ which corresponds to the Rayner structural episode (Kelly et al., 2002; Kelly et al., 2012) and marks the final collision of India and East Antarctica (Dasgupta et al., 2017). Although petrological evidence was not found, monazite and zircon of high-grade rocks of the Phulbani area register $\sim 0.95-0.90 \mathrm{Ga}$ ages which suggest that this area possibly experienced reworking similar to the Visakhapatnam area during the above time-frame. Interestingly, the Angul area located to the north of the Phulbani area do not document evidence of the UHT metamorphism and zircon and monazite ages clustering between $\sim 0.98-0.95$ Ga (Aftalion et al., 1988; Mezger and Cosca, 1999) possibly indicating a granulite facies metamorphism during this time (Fig. 3c) (0.96-0.93 Ga, Sarkar et al., 2007). Such granulite facies metamorphism may correspond to the Rayner structural episode and in turn, indicates that the Angul area was originally part of the Rayner Complex and got attached to the EGP during $\sim 0.95 \mathrm{Ga}$. This is logical speculation which should be checked by detailed petrological and geochronological studies. Barring the UHT metamorphism at $\sim 0.98 \mathrm{Ga}$, tectonometamorphic events of $\sim 0.78$ and $0.52 \mathrm{Ga}$ in the Chilka Lake domain appear to be similar (Bose et al., 2016b) with the Prydz Bay region of East Antarctica (Fitzsimons, 2000). Based on this, the above authors proposed that the Chilka Lake domain was attached to the Prydz Bay region in East Antarctica within the framework of Rodinia, became separated at approximately $0.78 \mathrm{Ga}$ and united with rest of India (EGP in the present context) at approximately $0.52 \mathrm{Ga}$ as a part of East Gondwana. Metamorphic events of $\sim 0.85$ and $\sim 0.70 \mathrm{Ga}$ are also reported from the Angul area of the EGP as well (Halden et al., 1982; Lisker and Fachmann, 2001), indicating its consanguinity with the Prydz Bay region. This again should be checked by petrological and geochronological studies from the latter area which is poorly constrained in the existing literature.

On the basis of rigorous structural mapping and petrological investigation from the northwestern EGP and the $\mathrm{BC}$ contact, it is now successfully established that the granulite facies rocks of the EGP were thrusted over the cratonic rocks (Gupta et al., 2000; Bhadra et al., 2004). The metamorphic condition during such late Neoproterozoic thrusting was also estimated to reach up to amphibolite-granulite facies transition (Chatterjee et al., 2017b) and best documented in the rocks exposed at the shear zone (EGBSZ) marking the above contact. Although late Neoproterozoic to early Cambrian-aged thrust related tectonic evolution is also documented from the shear zone representing the contact of the northern EGP and the Rengali Province (Fig. 1) (Sarkar et al., 2007), it never attained granulite-facies metamorphic condition (Ghosh et al., 2016). Other shear zones present within the northern EGP namely the MSZ and the RSZ also do not document mineral growth pertaining to the granulite facies metamorphism (Bose and Gupta, 2018 for MSZ and P. Ganguly, unpublished data, 2019 for RSZ). All these pieces of evidence point towards the possibility that none of these shear zones represent the plate boundary marking the final amalgamation of India and East Antarctica in the context of the formation of the East Gondwana. Such a proposition, therefore, indicates the intra-cratonic nature of these shear zones which possibly resulted from the effect of far-field stresses generated at plate boundary with the lithosphere acting as an effective stress guide (Cawood et al., 2009; Raimondo et al., 2014). In the present scenario, such a plate boundary might have existed at East Antarctica (Kuunga suture of Boger et al., 2002) which remained the locus of deformation, metamorphism and magmatism during the final amalgamation of the greater Indian land- 
mass with the East Antarctic shield at the early Paleozoic time (Collins and Pisarevsky, 2005; Boger, 2011; PD1 of Harley et al., 2013;). The above idea is also supported by the work of Ravikant (2019) who proposed Cambrian-age amphibolite facies reworking of the granulites along intracrustal shear zones. On the other hand, in recent work using receiver function analyses across the EGB-BC, Singh and Singh (2019) interpreted major shear zones as collisional sutures that juxtaposed crustal domains of EGP during the formation of the Rodinia and Gondwana supercontinents. This interpretation is based on the Moho offsets in the tune of $\sim 5 \mathrm{~km}$ across the crustal domain boundaries of Dobmeier and Raith (2003). However, such an assumption appears to be inconsistent with the recent geological and geochronological data (Ganguly et al., 2017, 2018).

\section{CONCLUDING REMARKS}

The above review gives a brief idea about the geological evolution of the northern and the northwestern parts of the EGB. Some outstanding issues, however, exist regarding the tectonic framework involving this portion of the EGB which are mentioned below and further studies involving structural, petrological and isotopic works are required to solve these issues.

1) The $\sim 1.17-1.16 \mathrm{Ga}$ ages from the Phulbani and the Angul areas indicate granitic magmatism which on cooling formed the basement for sediment deposition and subsequent metamorphism. Alkaline magmatism of $\sim 1.32 \mathrm{Ga}$ from the northern part of the EGB and the $\sim 1.26-1.20 \mathrm{Ga}$ granulite facies metamorphism from the Angul area could be related to the above basement forming event which is obviously a mere speculation and needs further investigations.

2) Absence of UHT metamorphism of $\sim 1.0 \mathrm{Ga}$ and abundance of monazite ages spanning $\sim 0.98-0.95$ $\mathrm{Ga}$ from the Angul area possibly suggest its accretion with the rest of the EGB during this time. In addition to this, metamorphic events of $\sim 0.85$ and $\sim 0.70 \mathrm{Ga}$ from the Angul area indicate a probable connection with the Prydz Bay region of East Antarctica.

3) The UHT metamorphic event at the Deobhog area of the northwestern EGB was correlated with the 0.55$0.50 \mathrm{Ga}$ thrusting of the EGB over the BC. This appears to be contradictory in the context of $\sim 1.06$ Ga UHT metamorphism in the same area.

4) Absence of high-grade metamorphic imprints from the major shear zones of the northern EGB namely the MSZ and the RSZ indicate their formation in an intra-cratonic setting possibly during the formation of the East Gondwana. The actual plate boundary during this time might have existed at East Antarc- tica which remained the key area of metamorphism, magmatism and deformation.

\section{ACKNOWLEDGMENTS}

We are thankful to Prof. Jun-Ichi Ando and Prof. Kaushik Das for the invitation to contribute to the volume. We would like to express our sincere gratitude to Prof. Sankar Bose, Prof. Kaushik Das and Prof. Gautam Ghosh for their guidance and support which always motivated us to continue our research. We thank Subhadip Bhadra and an anonymous reviewer for their suggestions which improved the quality of the manuscript. We convey our gratitude to Supriya Chakraborty of the Geological Survey of India for providing toposheets of the Phulbani and the adjoining areas.

\section{REFERENCES}

Aftalion, M., Bowes, D.R., Dash, B. and Dempster, T.J. (1988) Late Proterozoic charnockites in Orissa, India: A U-Pb and $\mathrm{Rb}-\mathrm{Sr}$ isotopic study. The Journal of Geology, 96, 663-675.

Bhadra, S., Gupta, S. and Banerjee, M. (2004) Structural evolution across the Eastern Ghats Mobile Belt-Bastar craton boundary, India: hot over cold thrusting in an ancient collision zone. Journal of Structural Geology, 26, 233-245.

Bhadra, S., Das, S. and Bhattacharya, A. (2007) Shear zone-hosted migmatites (Eastern India): the role of dynamic melting in the generation of REE-depleted felsic melts, and implications for disequilibrium melting. Journal of Petrology, 48, 435-457.

Bhattacharya, S. (2004) High-temperature crustal scale shear zone at the western margin of the Eastern Ghats granulite belt, India: implications for rapid exhumation. Journal of Asian Earth Sciences, 24, 281-290.

Bhowmik, S.K. (2019) The current status of orogenesis in the Central Indian Tectonic Zone: A view from its Southern Margin. Geological Journal. https://doi.org/10.1002/gj.3456

Biswal, T.K., DeWaele, B. and Ahuja, H. (2007) Timing and dynamics of the juxtaposition of the Eastern Ghats mobile belt against the Bhandara Craton, India: a structural and zircon $\mathrm{U}-\mathrm{Pb}$ SHRIMP study of the fold-thrust belt and associated nepheline syenite plutons. Tectonics, 26, TC4006.

Boger, S.D. (2011) Antarctica-before and after Gondwana. Gondwana Research, 19, 335-371.

Boger, S.D., Carson, C.J., Fanning, C.M., Hergt, J.M., et al. (2002) Pan-African intraplate deformation in the northern Prince Charles Mountains, East Antarctica. Earth and Planetary Science Letters, 195, 195-210.

Bose, S., Das, K. and Arima, M. (2008) Multiple stages of melting and melt-solid interaction in the lower crust: new evidence from UHT granulites of Eastern Ghats Belt, India. Journal of Mineralogical and Petrological Sciences, 103, 266-272.

Bose, S., Dunkley, D.J., Dasgupta, S., Das, K. and Arima, M. (2011) India-Antarctica-Australia-Laurentia connection in the Paleo-Mesoproterozoic revisited: evidence from new zircon $\mathrm{U}-\mathrm{Pb}$ and monazite chemical age data from the Eastern Ghats Belt, India. Geological Society of America Bulletin, 123, 2031-2049.

Bose, S., Guha, S., Ghosh, G., Das, K. and Mukhopadhyay, J. 
(2015) Tectonic juxtaposition of crust and continental growth during orogenesis: Example from the Rengali Province, eastern India. Geoscience Frontiers, 6, 537-555.

Bose, S., Das, K., Kimura, K., Hidaka, H., et al. (2016a) Neoarchean tectonothermal imprints in the Rengali Province, eastern India and their implication on the growth of Singhbhum Craton: evidence from zircon U-Pb SHRIMP data. Journal of Metamorphic Geology, 34, 743-764.

Bose, S., Das, K., Torimoto, J., Arima, M. and Dunkley, D.J. (2016b) Evolution of the Chilka Lake granulite complex, northern Eastern Ghats Belt, India: First evidence of $\sim 780$ Ma decompression of the deep crust and its implication on the India-Antarctica correlation. Lithos, 263, 161-189.

Bose, S. and Dasgupta, S. (2018) Eastern Ghats Belt, Grenvillianage tectonics and the evolution of the Greater Indian Landmass: a critical perspective. Journal of the Indian Institute of Science, doi:10.1007/s41745-018-0068-2.

Bose, S. and Gupta, S. (2018) Strain partitioning along the Mahanadi Shear Zone: Implications for paleo-tectonics of the Eastern Ghats Province, India. Journal of Asian Earth Sciences, 157, 269-282.

Brandt, S., Schenk, V., Raith, M.M., Appel, P., et al. (2011) Late Neoproterozoic P-T evolution of HP-UHT granulites from the Palni Hills (South India): new constraints from phase diagram modelling, LA-ICP-MS zircon dating and in-situ EMP monazite dating. Journal of Petrology, 52, 1813-1856.

Cawood, P.A., Kröner, A., Collins, W.J., Kusky, T.M., et al. (2009) Accretionary orogens through Earth history. In Earth Accretionary Systems in Space and Time (Cawood, P.A. and Kröner, A. Eds.). Geological Society, London, Special Publications, 318, 1-36.

Chakrabarti, R., Basu, A.R., Bandyopadhyay, P.K. and Zou, H. (2011) Age and origin of the Chilka anorthosites, Eastern Ghats, India: implications for massif anorthosite petrogenesis and break-up of Rodinia. In Topics in Igneous Petrology (Ray, J., Sen, G. and Ghosh, B. Eds.). Springer, 355-382.

Chatterjee, A., Das, K., Bose, S., Ganguly, P. and Hidaka, H. (2017a) Zircon U-Pb SHRIMP and monazite EPMA U-Thtotal $\mathrm{Pb}$ geochronology of granulites of the western boundary, Eastern Ghats Belt, India: new possibility for Neoproterozoic exhumation history. In Crustal Evolution of India and Antarctica: The Supercontinent Connection (Pant, N.C. and Dasgupta, S. Eds.). Geological Society, London, Special Publications, 457, 105-140.

Chatterjee, A., Das, K., Bose, S. and Hidaka, H. (2017b) Age-integrated tectonic evolution across the orogen-craton boundary: age zonation and shallow-to deep crustal participation during Late Cambrian cratonisation of Eastern Ghats Belts, India. Lithos, 290-291, 269-293.

Chatterjee, N., Crowley, J.L., Mukherjee, A. and Das, S. (2008) Geochronology of the 983-Ma Chilka Lake Anorthosite, Eastern Ghats Belt India: implications for Pre-Gondwana tectonics. Journal of Geology, 116, 105-118.

Chattopadhyay, S., Upadhyay, D., Nanda, J.K., Mezger, K., et al. (2015) Proto-India was a part of Rodinia: evidence from Grenville-age suturing of the Eastern Ghats Province with the Paleoarchean Singhbhum Craton. Precambrian Research, 266, 506-529.

Collins, A.S. and Pisarevsky, S.A. (2005) Amalgamating eastern Gondwana: the evolution of the Circum-Indian Orogens. Earth-Science Reviews, 71, 229-270.

Crowe, W.A., Cosca, M.A. and Harris, L.B. (2001) ${ }^{40} \mathrm{Ar} /{ }^{39} \mathrm{Ar}$ geo- chronolgy and Neoproterozoic tectonics along the northern margin of the Eastern Ghats Belt in north Orissa, India. Precambrian Research, 108, 237-266.

Crowe, W.A., Nash, C.R., Harris, L.B., Leeming, P.M. and Rankin, L.R. (2003) The geology of the Rengali Province: implications for the tectonic development of northern Orissa, India. Journal of Asian Earth Sciences, 21, 697-710.

Das, E., Karmakar, S., Dey, A., Karmakar, S. and Sengupta, P. (2017) Reaction textures, pressure-temperature paths and chemical dates of monazite from a new suite of sapphirinespinel granulites from parts of the Eastern Ghats Province, India: insights into the final amalgamation of India and East Antarctica during the formation of Rodinia. In Crustal Evolution of India and Antarctica: The Supercontinent Connection (Pant, N.C. and Dasgupta, S. Eds.). Geological Society, London, Special Publications, 457, 141-170.

Das, K., Yokoyama, K., Chakraborty, P.P. and Sarkar, A. (2009) Basal Tuffs and Contemporaneity of the Chattisgarh and Khariar Basins Based on New Dates and Geochemistry. Journal of Geology, 117, 88-102.

Das, K., Bose, S., Karmakar, S., Dunkley, D.J. and Dasgupta, S. (2011a) Multiple tectonometamorphic imprints in the lower crust: first evidence of $\sim 950 \mathrm{Ma}$ (zircon U-Pb SHRIMP) compressional reworking of UHT aluminous granulites from the Eastern Ghats Belt, India. Geological Journal, 46, 217-239.

Das, K., Bose, S., Karmakar, S. and Chakraborty, S. (2012) Petrotectonic framework of granulites from northern part of Chilka Lake area, Eastern Ghats Belt, India: Compressional vis-à-vis transpressional tectonics. Journal of Earth System Science, 121, 1-17.

Das, K., Chakraborty, P.P., Hayasaka, Y., Kayama, M., et al. (2015) c. 1450 Ma regional felsic volcanism at the fringe of the East Indian Craton: Constraints from geochronology and geochemistry of tuff beds from detached sedimentary basins. In Precambrian Basins of India: Stratigraphic and Tectonic Context (Mazumder, R. and Eriksson, P.G. Eds.). Geological Society, London Memoirs, 43, 207-221.

Das, P., Das, K., Chakraborty, P.P. and Balakrishnan, S. (2011b) 1420 Ma diabasic intrusives from the Mesoproterozoic Singhora Group, Chhattisgarh Supergroup, India: Implications towards non-plume intrusive activity. Journal of Earth System Sciences, 120, 223-236.

Das, S., Nasipuri, P., Bhattacharya, A. and Swaminathan, S. (2008) The thrust-contact between the Eastern Ghats Belt and the adjoining Bastar craton (Eastern India): evidence from mafic granulites and tectonic implications. Precambrian Research, $162,70-85$.

Dasgupta, S. and Sengupta, P. (2003) Indo-Antarctic correlation: a perspective from the Eastern Ghats granulite belt, India. In Proterozoic East Gondwana: Supercontinent Assembly and Breakup (Yoshida, M., Windley, B.E. and Dasgupta, S. Eds.). Geological Society, London, Special Publications, 206, 131143.

Dasgupta, S., Bose, S. and Das, K. (2013) Tectonic evolution of the Eastern Ghats Belt. Precambrian Research, 227, 247-258.

Dasgupta, S., Bose, S., Bhowmik, S.K. and Sengupta, P. (2017) The Eastern Ghats Belt, India, in the context of supercontinent assembly. In Crustal Evolution of India and Antarctica: The Supercontinent Connection (Pant, N.C. and Dasgupta, S. Eds.). Geological Society, London, Special Publications, 457, 87-104.

Dharma Rao, C.V., Santosh, M. and Zhang, S.H. (2014) Neoproterozoic massif-type anorthosites and related magmatic suites 
from the Eastern Ghats Belt, India: Implications for slab window magmatism at the terminal stage of collisional orogeny. Precambrian Research, 240, 60-78.

Dobmeier, C. (2006) Emplacement of Proterozoic massif-type anorthosite during regional shortening: evidence from the Bolangir anorthosite complex (Eastern Ghats Province, India). International Journal of Earth Sciences, 95, 543-555.

Dobmeier, C. and Simmat, R. (2002) Post-Grenvillian transpression in the Chilka Lake area, Eastern Ghats Belt - implications for the geological evolution of peninsular India. Precambrian Research, 113, 243-268.

Dobmeier, C. and Raith, M.M. (2003) Crustal architecture and evolution of the Eastern Ghats Belt and adjacent regions of India. In Proterozoic East Gondwana: supercontinent assembly and breakup (Yoshida, M., Windley, B.F., Dasgupta, S. Eds.). Geological Society, London, Special Publications, 206, 145168.

Duchesne, J.C., Liégeois, J.P., Auwera, J.V. and Longhi, J. (1999) The crustal tongue melting model and the origin of massive anorthosites. Terra Nova, 11, 100-105.

Fitzsimons, I.C.W. (2000) A review of tectonic events in the East Antarctic Shield and their implications for Gondwana and earlier supercontinents. Journal of African Earth Science, 39, 173-193.

Ganguly, P., Bose, S., Das, K., Torimoto, J. and Ghosh, G. (2017) Origin of Spinel+ Quartz Assemblage in a Si-undersaturated Ultrahigh-temperature Aluminous Granulite and its Implication for the P-T-fluid History of the Phulbani Domain, Eastern Ghats Belt, India. Journal of Petrology, 58, 1941-1974.

Ganguly, P., Das, K., Bose, S., Ghosh, G., et al. (2018) U-Pb zircon and $\mathrm{U}-\mathrm{Th}$-total $\mathrm{Pb}$ monazite ages from the Phulbani domain of the Eastern Ghats Belt, India: Time constraints on high-grade metamorphism and magmatism in the lower crust. Precambrian Research, 316, 1-23.

Ghosh, G., Bose, S., Das, K., Dasgupta, A., et al. (2016) Transpression and juxtaposition of middle crust over upper crust forming a crustal scale flower structure: insight from structural, fabric, and kinematic studies from the Rengali Province, eastern India. Journal of Structural Geology, 83, 156-179.

Ghosh, J.G. (2004) 3.56 Ga tonalite in the central part of the Bastar craton, India: Oldest Indian date: Journal of Asian Earth Sciences, 23, 359-364. doi:10.1016/S1367-9120(03)00136-6

Gupta, S., Bhattacharya, A., Raith, M. and Nanda, J.K. (2000) Contrasting pressure-temperature-deformation history across a vestigial craton-mobile belt boundary: the western margin of the Eastern Ghats Belt at Deobhog, India. Journal of Metamorphic Geology, 18, 683-697.

Halden, N.M., Bowes, D.R. and Dash, B. (1982) Structural evolution of migmatites in granulite facies terrane: Precambrian crystalline complex of Angul, Orissa, India. Earth and Environmental Science Transactions of the Royal Society of Edinburgh, 73, 109-118.

Halpin, J., White, R.A., Clarke, G.L. and Kelsey, D.E. (2007) The Proterozoic P-T-t evolution of the Kemp Land Coast, East Antarctica; constraints from Si-saturated and Si-undersaturated metapelites. Journal of Petrology, 48, 1321-1349.

Harley, S.L. (2004) Extending our understanding of ultrahigh temperature crustal metamorphism. Journal of Mineralogical and Petrological Sciences, 99, 140-158.

Harley, S.L., Fitzsimons, I.C.W. and Zhao, Y. (2013) Antarctica and supercontinent evolution: historical perspectives, recent advances and unresolved issues. In Antarctica and Supercon- tinent Evolution (Harley, S.L., Fitzsimons, I.C.W. and Zhao, Y. Eds.). Geological Society, London, Special Publications, $383,1-34$.

Karmakar, S., Bose, S., Das, K. and Dasgupta, S. (2009) Proterozoic Eastern Ghats Belt, India: a witness of multiple orogenies and its lineage with ancient supercontinents. Journal of Virtual Explorer 32, http://dx.doi.org/10.3809/jvrtex.2009.00254.

Kelly, N.M., Clarke, G.L. and Fanning, C.A.M. (2002) A two stage evolution of the Neoproterozoic Rayner structural episode: new $\mathrm{U}-\mathrm{Pb}$ sensitive high resolution ion microprobe constraints from the Oygarden Group, Kemp Land, East Antarctica. Precambrian Research, 116, 307-330.

Kelly, N.M., Harley, S.L. and Möller, A. (2012) Complexity in the behavior and recrystallization of monazite during high-T metamorphism and fluid infiltration. Chemical Geology, 322, 192-208.

Kelsey, D.E., Morrissey, L.J., Hand, M., Clark, C., et al. (2017) Significance of post-peak metamorphic reaction microstructures in the ultrahigh temperature Eastern Ghats Province, India. Journal of Metamorphic Geology, 35, 1081-1109.

Korhonen, F.J., Clark, C., Brown, M., Bhattacharya, S. and Taylor, R. (2013) How long-lived is ultrahigh temperature (UHT) metamorphism? Constraints from zircon and monazite geochronology in the Eastern Ghats orogenic belt, India. Precambrian Research, 234, 322-350.

Krause, O., Dobmeier, C., Raith, M.M. and Mezger, K. (2001) Age of emplacement of massif type anorthosites in the Eastern Ghats Belt, India: constraints from U-Pb zircon dating and structural studies. Precambrian Research, 109, 25-38.

Lal, R.K., Ackermand, D. and Upadhyay, H. (1987) P-T-X relationships deduced from corona textures in sapphirine-spinelquartz assemblages from Paderu, southern India. Journal of Petrology, 28, 1139-1168.

Lisker, F. and Fachmann, S. (2001) Phanerozoic history of the Mahanadi region, India. Journal of Geophysical Research: Solid Earth, 106, 22,027-22,050.

Mezger, K. and Cosca, M.A. (1999) The thermal history of the Eastern Ghats Belt (India), as revealed by $\mathrm{U}-\mathrm{Pb}$ and ${ }^{40} \mathrm{Ar}-$ ${ }^{39}$ Ar dating of metamorphic and magmatic minerals: implications for the SWEAT correlation. Precambrian Research, 94, 251-271.

Morrissey, L.J., Hand, M. and Kelsey, D.E. (2015) Multi-stage metamorphism in the Rayner-Eastern Ghats Terrane: P-T-t constraints from the northern Prince Charles Mountains, east Antarctic. Precambrian Research, 267, 137-163.

Morrissey, L.J., Hand, M., Kelsey, D.E. and Wade, B.P. (2016) Cambrian high-temperature reworking of the Rayner-Eastern Ghats terrane: constraints from the northern Prince Charles Mountains region, East Antarctica. Journal of Petrology, 57, 53-92.

Mukhopadhyay, J., Beukes, N.J., Armstrong, R.A., Zimmermann, U., et al. (2008) Dating the Oldest Greenstone in India: A 3.51-Ga Precise U-Pb SHRIMP Zircon Age for Dacitic Lava of the Southern Iron Ore Group, Singhbhum Craton. Journal of Geology, 116, 449-461.

Nasipuri, P. and Bhadra, S. (2013) Structural framework for the emplacement of the Bolangir Anorthosite massif in the Eastern Ghats Granulite Belt, India: implications for post-Rodinia pre-Gondwana tectonics. Mineralogy and Petrology, 107, 861-880.

Nelson, D.R., Bhattacharya, H.N., Thern, E.R. and Altermann, W. (2014) Geochemical and ion-microprobe U-Pb zircon con- 
straints on the Archaean evolution of Singhbhum Craton, eastern India. Precambrian Research, 255, 412-432.

Neogi, S. and Das, N. (2000) Lithotectonic domains and metamorphic history of the boundary zone of the Eastern Ghats mobile belt and the Bastar craton, Deobhog area, Central India. Geological Survey of India Special Publication, 57, 180-204.

Olierook, H.K., Clark, C., Reddy, S.M., Mazumder, R., et al. (2019) Evolution of the Singhbhum Craton and supracrustal provinces from age, isotopic and chemical constraints. EarthScience Reviews, 193, 237-259.

Patranabis-Deb, S., Bickford, M.E., Hill, B., Chaudhuri, A.K. and Basu, A. (2007) SHRIMP Ages of Zircon in the Uppermost Tuff in Chattisgarh Basin in Central India Require $500 \mathrm{Ma}$ Adjustment in Indian Proterozoic Stratigraphy. Journal of Geology, 115, 407-415.

Paul, D.K., Ray Barman, T., McNaughton, N.J., Fletcher, I.R., et al. (1990) Archean-Proterozoic evolution of Indian charnockites: isotopic and geochemical evidence from granulites of the Eastern Ghats Belt. Journal of Geology, 98, 253-263.

Raimondo, T., Hand, M. and Collins, W.J. (2014) Compressional intracontinental orogens: Ancient and modern perspectives. Earth-Science Reviews, 130, 128-153.

Raith, M.M., Dobmeier, C. and Mouri, H. (2007) Origin and evolution of Fe-Al granulites in the thermal aureole of the Chilka Lake anorthosite, Eastern Ghats Province, India. Proceedings of Geological Association, 118, 87-100.

Raith, M.M., Mahapatro, S.N., Upadhyay, D., Berndt, J., et al. (2014) Age and P-T evolution of the Neoproterozoic Turkel Anorthosite Complex, Eastern Ghats Province India. Precambrian Research, 254, 87-113.

Rajesh, H.M., Mukhopadhyay, J., Beukes, N.J., Gutzmer, J., et al. (2009) Evidence for an early Archaean granite from Bastar craton, India. Journal of the Geological Society, 166, 193-196.

Ramakrishnan, M. (1990) Crustal development in southern Bastar, central India craton: Kolkata. Geological Survey of India Special Publication, 28, 44-66.

Ramakrishnan, M., Nanda, J.K. and Augustin, P. (1998) Geological evolution of the Proterozoic Eastern Ghats mobile belt. In Geological evolution of Proterozoic Eastern Ghats Mobile Belt (Ramakrishnan, M., Paul, D.K., Mishra, R.N. Eds.). Geological Survey of India Special Publication, 44, 1-21.

Ramakrishnan, M. and Vaidyanadhan, R. (2010) Geology of India: Bangalore. Geological Society of India.

Ranjan, S., Upadhyay, D., Abhinay, K., Pruseth, K.L. and Nanda, J.K. (2018) Zircon geochronology of deformed alkaline rocks along the Eastern Ghats Belt margin: India-Antarctica connection and the Enderbia continent. Precambrian Research, $310,407-424$.

Ravikant, V. (2019) Cambrian garnet Sm-Nd isotopic ages from the polydeformed Bolangir Anorthosite Complex, Eastern Ghats Belt, India: Implications for intraplate orogeny coeval with Kuunga Orogeny during Gondwana assembly. Journal of Geology, doi:10.1086/703463.

Rickers, K., Mezger, K. and Raith, M.M. (2001) Evolution of the continental crust in the Proterozoic Eastern Ghats Belt, and new constraints for Rodinia reconstruction: implications from $\mathrm{Sm}-\mathrm{Nd}, \mathrm{Rb}-\mathrm{Sr}$ and $\mathrm{Pb}-\mathrm{Pb}$ isotopes. Precambrian Research, $112,183-212$.

Santosh, M., Tsunogae, T., Tsutsumi, Y. and Iwamura, M. (2009) Microstructurally controlled monazite chronology of ultrahigh-temperature granulites from southern India: implications for the timing of Gondwana assembly. Island Arc, 18, 248-
265.

Sarkar, G., Corfu, F., Paul, D.K., McNaughton, N.J., et al. (1993) Early Archean crust in Bastar craton, central India-A geochemical and isotopic study. Precambrian Research, 62, 127137.

Sarkar, M., Gupta, S. and Panigrahi, M. (2007) Disentangling tectonic cycles along a multiply deformed terrane margin: Structural and metamorphic evidence for mid-crustal reworking of the Angul granulite complex, Eastern Ghats Belt, India. Journal of Structural Geology, 29, 802-818.

Sarkar, T., Schenk, V. and Berndt, J. (2015) Formation and evolution of a Proterozoic magmatic arc: geochemical and geochronological constraints from meta-igneous rocks of the Ongole domain, Eastern Ghats Belt, India. Contributions to Mineralogy and Petrology, 169, 1-27.

Sen, S.K., Bhattacharya, S. and Acharyya, A. (1995) A multi-stage pressure-temperature record in the Chilka Lake granulites: the epitome of the metamorphic evolution of Eastern Ghats, India? Journal of Metamorphic Geology, 14, 287-298.

Sengupta, P., Dasgupta, S., Dutta, N. and Raith, M.M. (2008) Petrology across a calc-silicate-anorthosite interface from the Chilka Lake Complex, Orissa: implications for Neoproterozoic crustal evolution of the Eastern Ghats Belt. Precambrian Research, 162, 40-58.

Simmat, R. and Raith, M.M. (2008) U-Th-Pb monazite geochronometry of the Eastern Ghats Belt, India: timing and spatial disposition of poly-metamorphism. Precambrian Research, $162,16-39$.

Singh, A. and Singh, C. (2019) Seismic imaging of the deep crustal structure beneath Eastern Ghats Mobile Belt (India): Crustal growth in the context of assembly of Rodinia and Gondwana supercontinents. Precambrian Research, 105343.

Stein, H.J., Hannah, J.L., Zimmerman, A., Markey, R.J., Sarkar, S.C. and Pal, A.B. (2004) A 2.5 Ga porphyry $\mathrm{Cu}-\mathrm{Mo}-\mathrm{Au}$ deposit at Malanjkhand, central India: Implications for Late Archean continental assembly. Precambrian Research, 134, 189-226.

Upadhyay, D., Raith, M.M., Mezger, K., Bhattacharya, A. and Kinny, P.D. (2006) Mesoproterozoic rifting and Pan-African continental collision in South-Eastern India: evidence from the Khariar alkaline complex. Contributions to Mineralogy and Petrology, 151, 434-456.

Upadhyay, D., Gerdes, A. and Raith, M.M. (2009) Unraveling sedimentary provenance and tectonothermal history of high to ultra-high temperature metapelites using zircon and monazite chemistry: a case study from the Eastern Ghats Belt, India. Journal of Geology, 117, 665-683.

Upadhyay, D., Chattopadhyay, S., Kooijman, E., Mezger, K. and Berndt, J. (2014) Magmatic and metamorphic history of Paleoarchean tonalite-trondhjemite-granodiorite (TTG) suite from the Singhbhum craton, eastern India. Precambrian Research, $252,180-190$.

Yamamoto, T., Ando, J., Tomioka, N., Das, K., et al. (2017) Microstructural observations of fracture-filling goethite vein along the Kerajang Fault Zone in the Rengali Province of eastern India. Journal of Mineralogical and Petrological Sciences, 112, 102-107.

Manuscript received August 27, 2019

Manuscript accepted January 21, 2020

Published online March 19, 2020

Manuscript handled by Kaushik Das Guest Editor 